\title{
ANATOMIC AND FUNCTIONAL ARRANGEMENT OF SUBEPICARDIAL ARTERIAL SYSTEM IN HUMAN HEART
}

Korobkeev A. A., Dolgashova M. A., Lezhnina O. Yu.

Stavropol State Medical University, Russian Federation

АНАТОМО-ФУНКЦИОНААЬНАЯ ОРГАНИЗАЦИЯ СУБЭПИКАРАИААЬНОГО АРТЕРИААЬНОГО РУСАА СЕРАЦА ЧЕАОВЕКА

\author{
А. А. Коробкеев, М. А. Аолгашова, О. Ю. Аежнина
}

\section{Ставропольский госуАарственный меАицинский университет, Российская ФеАерация}

The subepicardial arterial beds were studied in 60 hearts of people aged 21-60. The structural and functional values were identified for the coronary bed of people in their first and second mature ages, with the left, right, and equal types of coronary branching.

The presented morpho-functional arrangement of the subepicardial arterial bed describes specific features about vascularization in various topographic parts of the organ under investigation.

Key words: coronary arteries, structural and functional arrangement, morpho-functional indicators, first and the second stages of mature age

Изучено артериальное субэпикардиальное русло 60 сердец людей от 21 года до 60 лет. Определены структурно-функциональные показатели коронарного русла людей первого и второго периодов зрелого возраста с левовенечным, правовенечным и равномерным вариантами ветвлений венечных артерий.

Представленная морфофункциональная организация субэпикардиального артериального русла сердца характеризует особенности васкуляризации различных топографических отделов органа.

Ключевые слова: венечные артерии, структурно-функциональная организация, морфофункциональные показатели, первый и второй периоды зрелого возраста

schemic heart disease is rated among the most common mortality causes nowadays $[2,8,10]$. If

compared to well-developed nations, in Russia this disease accounts for 3-9 times as many deaths [1, 11]. This explains the extensive interest that both applied healthcare and morpho-cardiology take in the structural arrangement of the arterial bed in human heart, in view of its morpho-functional features.

Literature has been studied focusing on age-specific subepicardial arterial branchings [3-7, 9]; however there is no systemic data on the structural and functional arrangement of vascular bifurcations of coronary arteries (CA), which would take into account their major morphofunctional indicators at various types of CA branching in the first and the second stages of mature age.

Aim of study was to offer a view on the structure of the human subepicardial arterial bed in the first and the second stages of mature age based on the structural and functional arrangement of macro-vascular CA branching and their secondary arborizations.

Material and Methods. Subepicardial CA branches were investigated from 60 hearts obtained through autopsy from male and female bodies in their first and second stages of maturity (21-60 yrs) who were killed in accidents or passed away due to a pathology not involving cardiovascular system.

Anatomic, morphometric, histological, and X-ray methods were employed to study arterial angioarchi- tecture and cross sections of the CA and their branches. The coronaries were studied, with the respective data processed and comparative analysis done, using special computer software (Videotest-Morphology, 5.0). The branching angles were broken in three groups (below $45^{\circ}$; $45^{\circ}-90^{\circ}$; above $90^{\circ}$ ). The obtained morpho-functional indicators for vascular branching allowed developing effective morpho-mathematical models for CA and their branches as well as respective graphs for the alternating total cross section ( $\Sigma$ Ssect).

Results and Discussion. Comparative analysis of CA total cross section at various types of branching in people in their first stage of the mature age has shown that in all the hearts with left coronary, right coronary and equal CA branching the total cross section of the branches in the left coronary artery (LCA) prevailed over the $\Sigma$ Ssect in the vascular branching of the right coronary artery (RCA) except their end-points in case of right coronary branching where the RCA total cross section exceeds that of the LCA.

Comparative analysis of the total CA opening in the second stage of the mature age has shown that in the major area in case of left coronary and equal type of coronary arborization $\Sigma$ Ssect of the main branches of the LCA dominates over the $\Sigma$ Ssect of the RCA. The only exception to it was the right coronary branching where the total opening of the LCA was above that of the RCA at the initial parts alone. 
Comparative analysis of the $\Sigma$ Ssect of CA at various types of branching in the first stage of the mature age has revealed the prevalence of the total opening in case of left coronary type compared to the equal and the right coronary arborization types. The maximum values of the total cross section of the RCA main branches were registered in case of the right coronary type of arborization (compared to the left and equal coronary types) in the most area of the branch coverage.

The prevalence of the LCA $\Sigma$ Ssect in the second stage of the mature age was to be observed in all the initial parts of its branching in case of left coronary arborization as well as at the end-points at equal-coronary arborization with minimal values for the respective indices in case of the right coronary type of branching.

The total cross section of the RCA is maximal at equal coronary branching at the initial parts of the CA arborizations. In case of right coronary branching the total cross section was at its highest value at the end-points of its branch coverage if compared to the left coronary type of branching where the total vascular opening was at its minimum.

Comparative analysis of the total LCA opening at various types of coronary arborization through the investigated age stages has shown its maximum values and prevalence over the entire area of branching only in case of the left coronary type in the first stage of the mature age. In case of the right coronary arborization in the first stage of the mature age, LCA $\Sigma$ Ssect also prevails in the largest part of its coverage except the initial parts where the indices in question in the first and the second mature-age stages are much the same. The equal type of coronary artery arborization can be described with larger values for the $\Sigma$ Ssect in relation to the main LC branches in the second mature age, from its initial parts up to entering the myocardium, compared to the first mature age.

The total opening of the main RCA branches is prevailing in the largest area in all variants of coronary branching in the second mature age whereas the only exception were the initial parts at the right coronary type, and the endpoints at the left coronary type of artery branching where they were about equal or slightly below if put against the first mature age. The maximal values of the RCA branches $\Sigma$ Ssect were identified in the second mature age in case of equal coronary branching, and in the first mature age - at the right coronary type of branching, if compared to the left coronary and the equal coronary types.

\section{References}

1. Boytsov S. A., Dovgalevsky P. Ya., Gridnev V. I. Sravnitelny analiz dannykh Rossyskogo i zarubezhnykh registrov ostrogo koronarnogo sindroma. Kardiologichesky vestnik. - Cardiology Vestnik. 2010;1:82-86.

2. Zabolevayemost naseleniya Rossii v 2007 godu. Statisticheskiye materialy. M.; 2008.

3. Korobkeyev A. A., Lezhnina O. Yu., Basakov M. A. Morfofunktsionalnye parametry krovenosnogo rusla serdtsa u lyudey pervogo i vtorogo periodov zrelogo vozrasta. Fundamentalnye issledovaniya. - Fundamental research. 2011;10:509-512.

4. Lezhnina O. Yu., Korobkeyev A. A. Dinamika izmeneniya koeffitsiyenta suzheniya summarnogo prosveta arterialnogo rusla serdtsa. Morfologiya. - Morphology. 2014; $145(3): 115$.

5. Lezhnina O. Yu., Korobkeyev A. A. Osobennosti organizatsii koronarnogo rusla serdtsa pri razlichnykh variantakh vetvleny venechnykh artery. Meditsinsky vestnik Severnogo Kavkaza. - Medical News of North Caucasus. 2015;10(1):88-91.

6. Lezhnina O. Yu., Korobkeyev A. A., Fedko I. I. Sovremennye morfofunktsionalnye parametry arterialnogo rusla serdtsa. Astrakhansky meditsinsky zhurnal. - Astrakhan Medical Journal. 2012:4:166-168.

7. Lezhnina O. Yu., Korobkeyev A. A. Kharakteristika subepikardialnykh koronarnykh razvetvleny serdets
In most of the studied age stages at all types of coronary arborization, the total number of vascular CA branchings with angles within the range of $45^{\circ}-90^{\circ}$ was above the number of those with an angle below $45^{\circ}$ as well as above $90^{\circ}$.

In those in their first mature age, at the left coronary type of arborization, the share of the angles $45^{\circ}-90^{\circ}$, below $45^{\circ}$, and above $90^{\circ}$ was $55 \%, 25 \%$, and $20 \%$ respectively. In case of the right coronary type, the angles of the affiliated branches lying within $45^{\circ}-90^{\circ}$ were observed in $76.5 \%$ of the cases, while another $23.5 \%$ were identified as angles below $45^{\circ}$. The equal-coronary type of arborization revealed $61.1 \%$ of branching angles at $45^{\circ}-90^{\circ}, 27.8 \%$ of cases below $45^{\circ}$, with the rest of those $(11.1 \%)$ - above $90^{\circ}$.

In cases of the second mature age, with the left coronary type of arborization, the balance of the branching angles was as follows: $45^{\circ}-90^{\circ}-73.3 \%$; below $45^{\circ}-20 \%$, and over $90^{\circ}-6.7 \% .70 .6 \%$ of the cases with the right coronary branching were observed to have the angles of $45^{\circ}-90^{\circ}, 11.8 \%$ - below $45^{\circ}$, with another $17.6 \%$ being above $90^{\circ}$. However, in the cases of CA equal branching the values were distributed like $55 \%$, $25 \%$, and $20 \%$ for the angles of $45^{\circ}-90^{\circ}$, below $45^{\circ}$, and above $90^{\circ}$, respectively.

At all coronary branching types, the maximal branching with a bigger deviation angle and smaller Ssect (compared to less-deviating branches with a larger Ssect) was $78.2 \%$ for the first mature age, while in the second mature age there were fewer cases like that $(76.9 \%)$. Along with that, there were vascular branching types identified where more deviating branches had a larger value of the Ssect compared to those with a smaller deviation angle and a lower value of the Ssect. Their share in the first and in the second mature ages was $20 \%$ and $23.1 \%$, respectively. The arborization types with affiliated branches of equal-angle deviation and showing various Ssect were identified only in the first mature age, in $1.8 \%$ of all the cases.

Conclusions. Therefore, the dynamics for the total opening change in the studied blood vessels correlates with the topography of the CAs and that of their branches under various types of coronary arborization through the age stages of the postnatal ontogenesis, which is reflected in the specific features of the morphomathematical models.

lyudey pervogo i vtorogo detstva. Zhurnal teoreticheskoy i prakticheskoy meditsiny. - Journal of theoretical and practical medicine. 2010;8:144-145.

8. ESC Guidelines for the management of acute coronary syndromes in patients presenting without persistent ST segment elevation. The Task Force for the management of acute coronary syndromes in patients presenting without persistent ST segment elevation of the European Society of Cardiology. Eur. Heart J. 2011;32:29993054.

9. Lezhnina O. Yu., Korobkeyev A. A. Specific features of the arterial vascularization in the heart under normal conditions and in myocardial infarction. Medical News of North Caucasus. 2014;9(2):173-174.

10. Thom $\mathrm{T}$, Haase N., Rosamond W. American Heart Association Statistics Committee and Stroke Statistics Subcommittee. Heart disease and stroke statistics 2006 update: a report from the American Heart Association Statistics Committee and Stroke Statistics Subcommittee. Circulation. 2006;113:85-151.

11. Tu J. V., Nardi L., Fang J., Liu J. Canadian Cardiovascular Outcomes Research Team. National trends in rates of death and hospital admissions related to acute myocardial infarction, heart failure and stroke, 19942004. CMAJ. 2009;180(13):118-125. 


\author{
About authors: \\ Korobkeyev Alexander, MD, PhD, Professor; Head of Department of Anatomy; \\ tel.: +7(8652)353229; e-mail: Korobkeev@Stgma.ru \\ Dolgashova Marina, MD, PhD; Associate Professor, Department of Histology; \\ tel.: +7(8652)353440; e-mail: dolgashova@mail.ru \\ Lezhnina Oksana, MD, PhD; Associate Professor, Department of Anatomy; \\ tel.: +7(8652)353229; e-mail: okliz26@mail.ru
}

(๑) Group of autors, 2016

UDC 616.37-002-08

DOI - http://dx.doi.org/10.14300/mnnc.2016.11042

ISSN 2073-8137

\title{
RESULTS OF ACUTE PANCREATITIS TREATMENT IN SURGERY DEPARTMENT CLINIC OF STAVROPOL STATE MEDICAL UNIVERSITY
}

\author{
Suzdaltsev I. V., Ionov P. Sh., Pechenkin E. V., Bondarenko A. G., Panchenko A. S. \\ Stavropol State Medical University, Russian Federation

\section{РЕЗУАЬТАТЫ АЕЧЕНИЯ ОСТРОГО ПАНКРЕАТИТА В КАИНИКЕ ФАКУАЬТЕТСКОЙ ХИРУРГИИ СТАВРОПОАЬСКОГО ГОСУААРСТВЕННОГО МЕАИЦИНСКОГО УНИВЕРСИТЕТА}

\author{
И. В. СузАальцев, П. Ш. Ионов, Е. В. Печёнкин, А. Г. Бондаренко, А. С. Панченко \\ Ставропольский госуАарственный меАицинский университет, Российская ФеАерация
}

The analysis of results of treatment of patients with acute pancreatitis in the clinic of faculty surgery, Stavropol state medical University for 30 years. For the period 1984-2014 in the clinic of faculty surgery enrolled 4010 patients with acute pancreatitis. The leading etiological factor in the development of acute pancreatitis was alimentary. Overall mortality was $2.1 \%$. Of 4010 operated 321 (8\%), after surgery died 60 (18,6 \%) patients. Postoperative mortality in 1984-1997, he was $16.1 \%$, from 1998 to 2006 the values of this index varied in the range of $31 \%$, from 2007 to 2014 these numbers was of $13.8 \%$. This dynamics of postoperative mortality associated with the introduction of minimally invasive technologies. In patients treated conservatively, the mortality rate $0.7 \%$, which is due to the effectiveness of complex intensive pathogenetic therapy.

Key words: acute pancreatitis, analysis of the results, treatment

Проведён анализ результатов лечения больных острым панкреатитом в клинике факультетской хирургии Ставропольского государственного медицинского университета за 30 лет. За период 1984-2014 гг. в клинику факультетской хирургии поступило 4010 больных с острым панкреатитом. Ведущим этиологическим фактором в развитии острого панкреатита являлся алиментарный. Общая летальность составила $2,1 \%$. Из 4010 прооперировано 321 (8 \%), после операции умерло 60 (18,6 \%) больных. Послеоперационная летальность в 1984-1997 гг. составляла 16,1%, с 1998 по 2006 г. значения этого показателя варьировали в пределах 31 \%, начиная с 2007 по 2014 г. эти цифры соответствали 13,8 \%. Данная динамика послеоперационной летальности связана с внедрением малоинвазивных технологий. У больных, пролеченных консервативно, летальность составила 0,7 \%, что объясняется эффективностью комплексной интенсивной патогенетической терапией.

Ключевые слова: острый панкреатит, анализ результатов, лечение

P atients with acute pancreatitis account for $5-10 \%$ of the entire number of patients that belong to the surgical profile [3]. The latest decade has witnessed a rapidly increasing number of cases of acute pancreatitis, which has changed significantly the total structure of pathologies requiring emergency surgery. Acute pancreatitis tops the list of all other urgent abdominal issues - in 2004 the share of cases with acute pancreatitis was $31.3 \%$ out of the entire number of surgical hospitalizations, while in 1997 the patients in question made up only $21.5 \%$ of the entire number in the respective pathology group. In 2015, many regions had acute pancreatitis as the top common issue leaving behind all other urgent surgical abdominal pathologies [1]. 15-20\% of observed acute pancreatitis cases prove of destructive nature. In 40-70\% of patients with pancreatonecrosis get infected foci of necrotic destruction $[4,5]$. The mortality rate due to acute pancreatitis is up to $30 \%$. Infectious complications preceded by destructive pancreatitis account for $80 \%$ of the respective deaths [2]. Even though the methods for treating the disease have been improving for the latest $\mathbf{3 0}$ years, the mortality rate still remains 